GT2009-59568

\title{
ENGINE CONCEPTUAL DESIGN STUDIES FOR A HYBRID WING BODY AIRCRAFT
}

\author{
Michael T. Tong, Scott M. Jones, William J. Haller \\ National Aeronautics and Space Administration \\ Glenn Research Center \\ Cleveland, Ohio 44135 \\ Robert F. Handschuh \\ Army Research Laboratory \\ NASA Glenn Research Center \\ Cleveland, Ohio 44135
}

\begin{abstract}
Worldwide concerns of air quality and climate change have made environmental protection one of the most critical issues in aviation today. NASA's current Fundamental Aeronautics research program is directed at three generations of aircraft in the near, mid and far term, with initial operating capability around 2015, 2020, and 2030, respectively. Each generation has associated goals for fuel burn, $\mathrm{NO}_{\mathrm{x}}$, noise, and field-length reductions relative to today's aircrafts. The research for the 2020 generation is directed at enabling a hybrid wing body (HWB) aircraft to meet NASA's aggressive technology goals. This paper presents the conceptual cycle and mechanical designs of the two engine concepts, podded and embedded systems, which were proposed for a HWB cargo freighter. They are expected to offer significant benefits in noise reductions without compromising the fuel burn.
\end{abstract}

Keywords: hybrid wing body, fuel burn, noise, emissions

\section{INTRODUCTION}

More passengers and cargo are moved by air today than ever before, because of the global economy and worldwide connectivity. Over the next 15 to 20 years, the volume of air traffic is expected to at least double (for passenger traffic) or even triple (for cargo traffic) [1 and 2]. This robust growth rate causes growing concerns about the contribution that aircraft emissions will have on local air quality and global climate change. Chemical emissions of concern consist of anything that affects local air quality, global climate, or atmospheric ozone, including $\mathrm{CO}_{2}, \mathrm{NO}_{\mathrm{X}}$, sulfur oxides, water vapor and particulates [3]. For carbon based fuels, there is a 1:1 relationship between the amount of fuel burned and the amount of $\mathrm{CO}_{2}$ generated. Aviation noise can have adverse impacts on property values, airport expansion, and prompts operational restrictions on existing runways that increase congestion, leading to travel and shipping delays [4]. It is generally recognized that significant improvement to the environmental acceptability of aircraft will be needed to sustain long term growth. The ability of the nation to benefit from continued growth in aviation depends on the development of future aircrafts that can meet demanding environmental and performance challenges.

To achieve environmental protection that allows sustained long-term aviation growth, NASA has been engaged in the development of revolutionary aero-propulsion technologies and aircraft concepts with specific objectives to reduce aircraft fuel burn, noise, and $\mathrm{NO}_{\mathrm{x}}$ emissions while satisfying the field length constraints. Under the Subsonic Fixed Wing (SFW) project of its Fundamental Aeronautics Program, NASA's aeronautics research is directed at three generations of aircraft in the near, mid and far term, with initial operating capability (IOC) around 2015, 2020, and 2030, respectively. Each generation has associated goals for reductions in noise, emissions, fuel burn, and field length relative to today's aircraft. The three generations of aircraft are designated as ' $\mathrm{N}+1$ ', ' $\mathrm{N}+2$ ', and ' $\mathrm{N}+3$ ', respectively. The research for ' $\mathrm{N}+2$ ' and ' $\mathrm{N}+3$ ' are directed at enabling new vehicle configurations to meet NASA's aggressive technology goals. The ' $\mathrm{N}+1$ ' and ' $\mathrm{N}+2$ ' goals, as defined in the 2007 NASA Research Announcement request for proposal, are shown in Table 1.

TABLE 1.-NASA SUBSONIC FIXED WING SYSTEM-LEVEL GOALS

\begin{tabular}{|c|c|c|}
\hline & $\begin{array}{c}\text { N+1 generation } \\
\text { conventional } \\
\text { IOC 2015 }\end{array}$ & $\begin{array}{c}\text { N+2 generation } \\
\text { hybrid wing } \\
\text { IOC 2020 }\end{array}$ \\
\hline $\begin{array}{c}\text { Noise } \\
\text { (cumulative below Stage 4) }\end{array}$ & $-32 \mathrm{~dB}$ & $-42 \mathrm{~dB}$ \\
\hline $\begin{array}{c}\text { Landing-and-takeoff NO } \\
\text { emissions } \\
\text { (below CAEP/6) }\end{array}$ & $-60 \%$ & $-75 \%$ \\
\hline $\begin{array}{c}\text { Aircraft fuel burn } \\
\text { (relative to B737/CFM56) }\end{array}$ & $-15 \%{ }^{* *}$ & $-25 \%{ }^{* * *}$ \\
\hline
\end{tabular}

$* \mathrm{~N}+2$ baseline changed to B777/GE90 in 2008

** $-33 \%$ with laminar flow control

*** $-40 \%$ with laminar flow control

This material is declared a work of the U.S. Government and is not subject to copyright protection in the United States. Approved for public release; distribution is unlimited. 
NASA funded a 1-year Phase-1 effort to study the potential of a Hybrid Wing Body type aircraft to meet the $\mathrm{N}+2$ technology goals. This study was to focus on the noise goal of $-52 \mathrm{~dB}$ relative to Federal Aviation Regulations Part 36 (FAR 36) Stage 3 while meeting the fuel goal of $-25 \%$ relative to the current state-of-the-art aircraft. Boeing Phantom Works, teamed with Massachusetts Institute of Technology (MIT) and University of California Irvine, proposed to perform the study on a freighter aircraft. Both Boeing and Airbus forecasted the demand for cargo air traffic will grow at a higher rate than passenger airliners in the next twenty years $[1,2]$. The team was chosen to conduct the study.

Boeing, with its extensive background in blended wing body type aircraft, proposed two engine concepts for a hybrid wing body (HWB) freighter aircraft, for the 2020 timeframe the conventional pylon-mounted 'podded' and the futuristic 'embedded' systems. The HWB configurations with podded and embedded engines were designated as 'N2A' and 'N2B', respectively.

The N2A podded engine configuration was considered to be 'lower risk' for the 2020 timeframe, because of its low engine operability risk. The N2B with embedded engines was considered to be a 'higher risk' configuration, because of its complexities associated with closely coupled engine/airframe and boundary layer ingestion inlets. The closely coupled engine/airframe has the potential to reduce the engine-airframe integration penalties. The $\mathrm{N} 2 \mathrm{~B}$ was to be derived from the "Silent Aircraft" [5, 6]. The HWB aircraft-engine configurations with two types of engine are shown in Figure 1.

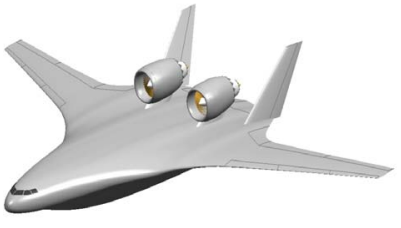

$\mathrm{N} 2 \mathrm{~A}$

(with podded engines)
$\mathrm{N} 2 \mathrm{~B}$

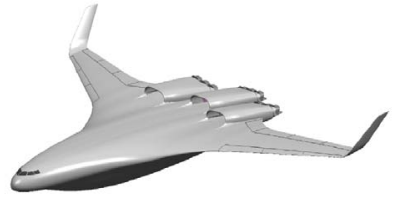

Figure 1. HWB aircraft-engine configurations.

Under the contractual agreement, NASA Glenn Research Center (GRC) agreed to perform engine conceptual design studies and provide the engine data to support Boeing's effort. The design studies were for four podded engines with fan pressure ratios (FPR) of 1.4, 1.5, 1.6, and 1.7, and one embedded engine with FPR1.5 (mutually agreed to be the same as the Silent Aircraft engine). This paper presents the conceptual cycle and mechanical designs of the two engine concepts proposed for the ' $\mathrm{N}+2$ ' generation freighter aircraft.

\section{HYBRID WING BODY (HWB) AIRCRAFT}

A hybrid wing body aircraft is an alternative airframe design in which the fuselage blends seamlessly with the wings to form a hybrid flying-wing configuration [7]. It also incorporates many design features from the conventional 'tube with wings' aircraft. Because of its high-lift wings and wide airfoil-shaped body (thus better aerodynamic efficiency), the HWB aircraft reduces the drag and fuel burn. Fully integrating the HWB airframe and the engines, e.g. embedded engines, will allow the aerodynamic efficiency to be maximized, which would further improve the aircraft performance. Also, if the engines are installed above the wing, the engine noise will be shielded by the aircraft's wide body and wing span and thus the aircraft will potentially operate quieter than the conventional aircraft.

A very quiet HWB airplane would not be limited by current operational curfews, such as night operations into noise-sensitive airports. The flexibility of operations, in combination with the worldwide trend towards widespread use of just-in-time delivery, would further stimulate the cargo growth and the demand for freighter aircrafts.

\section{Aircraft Mission Requirements}

Boeing defined the mission requirements for a HWB cargo freighter aircraft. They are:

- payload of 103,000 pounds;

- range of $6000 \mathrm{~nm}$;

- $35000 \mathrm{ft}$ initial cruise altitude or higher;

- time to climb through 31,000 ft not greater than 30 minutes;

- cruise Mach number of 0.8;

- field length of $10,000 \mathrm{ft}$ or less

\section{PROPULSION SYSTEM DESIGN}

\section{Propulsion System Design Requirements}

Based on the mission requirements defined by Boeing, GRC defined the propulsion system requirements, as follows:

For the podded twinjet engine system:

- aerodynamic design point (ADP):

Mach number0.8@31,000 ft;

thrust (per engine)=15000 lbs (@ International standard atmosphere (ISA +0)

- rolling takeoff (RTO) at Mach no. 0.25, sea level: thrust $($ per engine $)=54000 \mathrm{lb}(@ \mathrm{ISA}+15 \mathrm{C} / \mathrm{ISA}+27 \mathrm{~F})$;

For the embedded system (three engines, 9 fans):

- aerodynamic design point (ADP):

Mach number $0.8 @ 31,000 \mathrm{ft}$;

thrust (per engine)=10000 lbs (@ISA+0)

- rolling takeoff at Mach no. 0.25, sea level: thrust $($ per engine $)=36000 \mathrm{lb}(@$ ISA+15C/ISA+27F $)$;

\section{Engine Cycle Design}

Cycle design involves simultaneously solving aerodynamic design point and off-design parameters. Four podded engines with FPR of $1.4,1.5,1.6$, and 1.7 were modeled. Of these engines, the FPR1.4 and FPR1.5 engines were geared; the others were direct-drive. One embedded engine with FPR of 1.5 was modeled. It has three propulsion modules that were each composed of a gas generator that drove an inline fan and two additional outboard fans through a mechanical drive train.

The NASA software tool, NPSS (Numerical Propulsion System Simulation) [8 and 9], was used for this task that ultimately calculated engine thrust and specific fuel consumption for each of the engines. All engines were developed with the same ADP (Mach number, altitude, thrust). The ADP was selected to represent a nominal top-of-climb (TOC) condition for the hybrid wing airframe cargo freighter.

This material is declared a work of the U.S. Government and is not subject to copyright protection in the United States. Approved for public release; distribution is unlimited. 
TABLE 2.-GENERAL CYCLE CHARACTERISTICS OF PODDED ENGINE MODELS

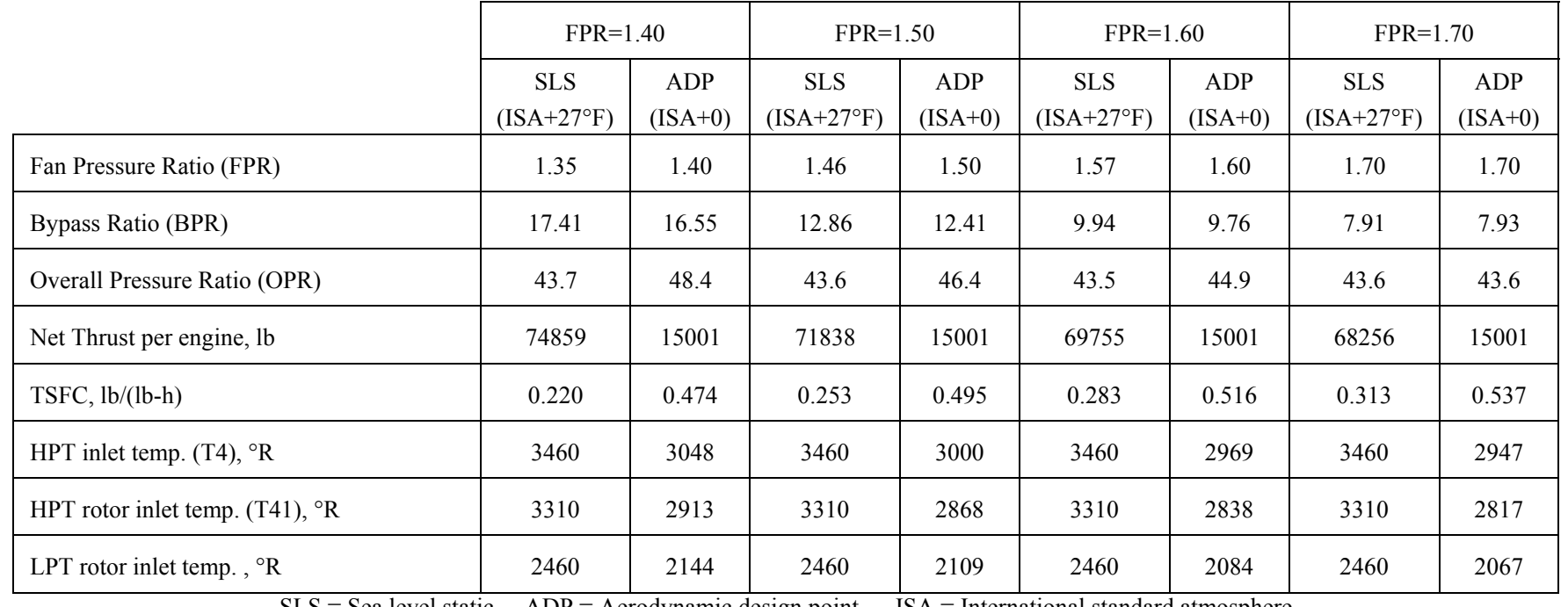

SLS $=$ Sea level static $\quad$ ADP $=$ Aerodynamic design point $\quad$ ISA $=$ International standard atmosphere

TABLE 3.-EMBEDDED ENGINE CYCLE PARAMETERS

\begin{tabular}{|l|c|c|}
\hline & $\begin{array}{c}\text { SLS } \\
\left(\text { ISA }+27^{\circ} \mathrm{F}\right)\end{array}$ & $\begin{array}{c}\text { ADP } \\
(\text { ISA+0) }\end{array}$ \\
\hline Fan Pressure Ratio (FPR) & 1.49 & 1.50 \\
\hline BPR (center or core engine only) & 3.2 & 3.1 \\
\hline Effective BPR (core and outboard engines) & 11.5 & 11.3 \\
\hline Overall Pressure Ratio (OPR) & 45 & 46 \\
\hline Net Thrust per engine (3 fans), lbs & 49060 & 10000 \\
\hline TSFC, lb/(lb-h) & 0.288 & 0.564 \\
\hline HPT inlet temp. (T4), ${ }^{\circ} \mathrm{R}$ & 3460 & 3010 \\
\hline HPT rotor inlet temp. (T41), ${ }^{\circ} \mathrm{R}$ & 3310 & 2876 \\
\hline LPT rotor inlet temp.,$~^{\circ} \mathrm{R}$ & 2460 & 2113 \\
\hline
\end{tabular}

Inlet mass flow for each engine was selected to achieve the net thrust requirement at ADP and bypass ratio was set to achieve an extraction ratio (ratio of total pressures for bypass nozzle and core nozzle) of 1.25 at the ADP for all engines. In addition to meeting a thrust target at TOC conditions, a sealevel rolling takeoff thrust target was also met by adjusting design point burner fuel-to-air ratio.

A maximum high-pressure turbine (HPT) inlet temperature of $3460{ }^{\circ} \mathrm{R}$ and maximum HPT rotor inlet temperature of $3310{ }^{\circ} \mathrm{R}$ (with cooling air) were assumed, reflecting the use of advanced high temperature materials. Also, a maximum low-pressure turbine (LPT) rotor inlet temperature of $2460 \mathrm{R}$ was used to eliminate the LPT cooling.

Assumptions for fan, low pressure compressor (LPC), efficiencies were based on technology trend curves recently developed by the Aerospace Systems Design Lab (ASDL) at Georgia Tech for use in the FAA's Environmental Design Space (EDS) system [10]. These curves have been reviewed by the EDS Independent Review Group, which includes industry representatives and is shown in Figures 2 and 3. For the high pressure compressor (HPC), a constant polytropic efficiency of $91.5 \%$ was assumed for all the engines. For the FPR1.4 and FRP1.5 engines, a variable area fan nozzle was needed to achieve the targeted $20 \%$ surge margin across the operating envelope. For the FPR1.6 and FPR1.7 engines, an acceptable surge margin was achievable with fixed geometry nozzles and the extra weight of a variable area nozzle was not justified.

General cycle characteristics of the podded engines are shown in Table 2. For the embedded engine, they are shown in Table 3. These data were generated with the inlet pressure recoveries provided by Boeing. For the podded engines, the inlet pressure recoveries were 0.998 at the ADP. For the embedded engine, they were 0.946 and 0.960 (with boundary layer ingestion) for the center and the side inlets, respectively.

\section{Engine Mechanical Design}

The podded-engine system for the HWB cargo freighter is a twinjet (2 engines) system. For this system, four engine designs with fan pressure ratios (FPR) of 1.4, 1.5, 1.6, and 1.7 were modeled. The basic common engine architecture for these engines is a two spool turbofan. Of these engines, the FPR1.4 and FPR1.5 engines were geared to reduce the number of LPC and LPT stages; the others were direct-drive.

The embedded-engine system for the HWB cargo freighter is a 3-engine configuration with a total of 9 fans. Each embedded engine is composed of a gas generator (core engine) that drove an inline fan and two additional outboard fans through a mechanical drive train. For this concept, one engine design with FPR of 1.5 was modeled.

The NASA software tool WATE (Weight Analysis of Gas Turbine Engines) [11, 12, 13] was used to create engine architectures that could achieve the engine thermodynamic cycle detailed in the previous section. Since WATE's original release in 1979, substantial improvements have been made to enhance its capability and improve its accuracy. Many of the empirical relationships have been replaced with analytical weight and dimension calculations. An approach is used where the stress level, maximum temperature and pressure, material, geometry, stage loading, hub-tip ratio, blade/vane counts, and shaft speed are used to determine the component weight. An updated gearbox-weight correlation is also included in the code.

The cycle data required for WATE execution, such as airflow, temperatures, and pressures, pressure ratios, bypass ratios, etc., was derived from NPSS output. Both the ADP and

This material is declared a work of the U.S. Government and is not subject to copyright protection in the United States. Approved for public release; distribution is unlimited. 
off-design cases were used to encompass the maximum performance level required for each engine component. This data, the material properties, and design rules for geometric, stress, and turbomachinery stage-loading limits were used to determine the acceptable engine layout.

Advanced materials were assumed to accommodate higher engine operating temperatures and to reduce the weight. A complete summary of the advanced engine materials assumed is shown in Table 4.

Both highly-loaded and conventional turbomachinery stage-loading cases were studied. Using highly-loaded turbomachinery can reduce the number of compressor and turbine stages, reducing component and engine weights and lengths, but with a trade-off of component and overall efficiency. Based on the results, it was mutually agreed between GRC and Boeing that the small differences in weight $(<2 \%)$ and overall dimensions $(<6 \%$ in length) would not compensate for the overall efficiency degradation with the highly-loaded turbomachinery. In this paper, only the results based on conventional turbomachinery loadings are presented.

For the podded engines the core nozzles were axisymmetric, and variable area fan nozzles were used for the FPR1.4 and FPR1.5 engines. It was assumed that the variablearea geometry (to be actuated by shape memory alloy) would increase the nozzle weight by $10 \%$ [14]. For the embedded engines, vectoring 2D variable-area nozzles were used. The length of the nozzle was set at 2 fan diameters to provide the space for the acoustic liners. Tables 5 and 6 summarize the parameters of the podded and embedded engines. The engine layouts for estimating performance and weights are shown in Figures 4 and 5. For the embedded engine, the boundarylayer-ingestion inlet and nacelles were considered part of the airframe and were designed by Boeing.

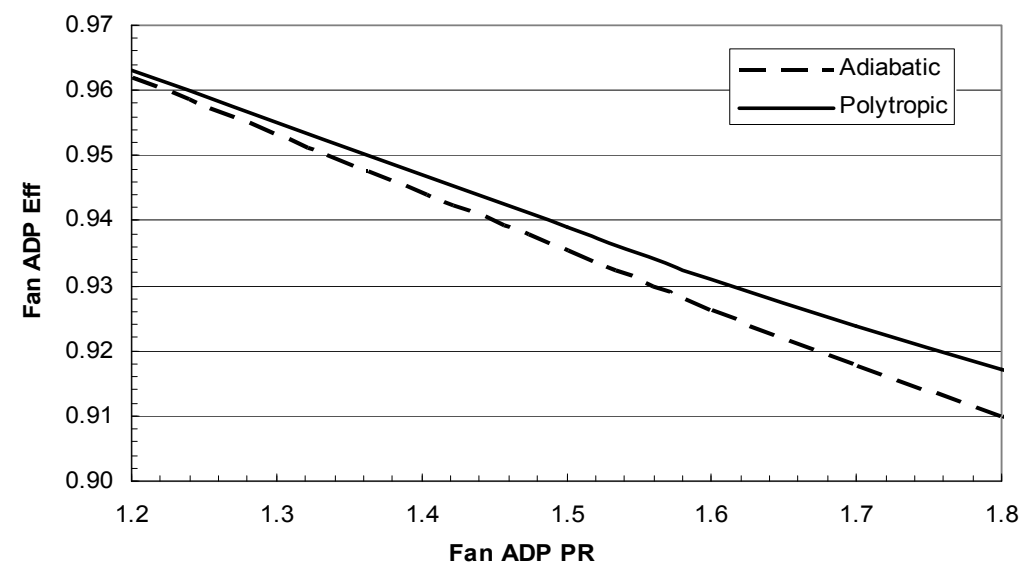

Figure 2. Variation of fan efficiency with pressure ratio (PR).

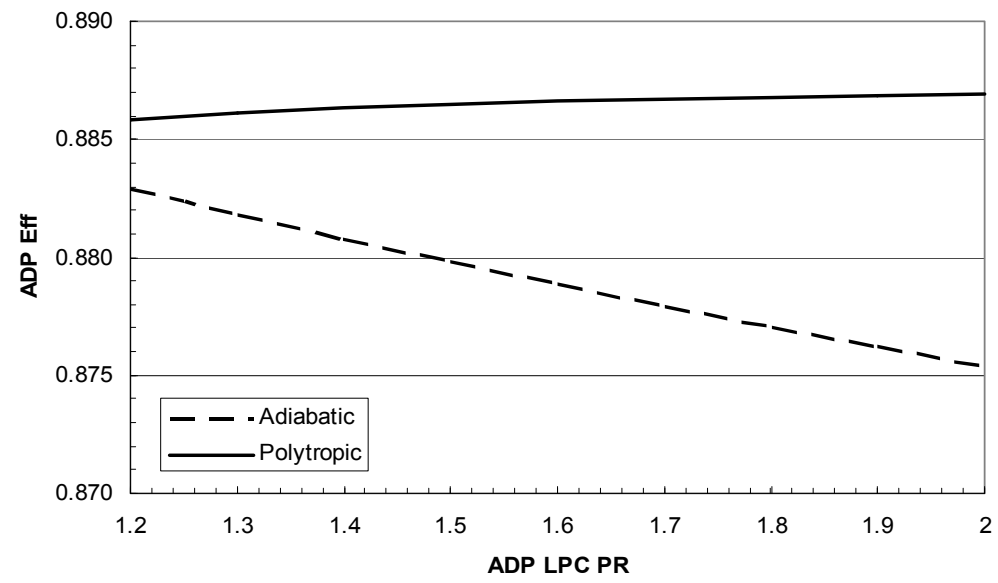

Figure 3. Variation of LPC efficiency with pressure ratio.

This material is declared a work of the U.S. Government and is not subject to copyright protection in the United States. Approved for public release; distribution is unlimited. 
TABLE 4.-ADVANCED ENGINE MATERIAL ASSUMPTIONS AND THEIR APPLICATIONS

\begin{tabular}{|c|c|c|c|c|}
\hline Component & Blade & Vane & Disk & Case \\
\hline Fan & $\begin{array}{c}\text { Polymer matrix } \\
\text { composite }\end{array}$ & $\begin{array}{c}\text { Polymer matrix } \\
\text { composite }\end{array}$ & $*$ & $\begin{array}{c}\text { Polymer matrix composite } \\
\text { wrapped by Zylon }\end{array}$ \\
\hline LPC & Titanium aluminide & Titanium aluminide & $*$ & $\begin{array}{c}\text { Titanium metal matrix } \\
\text { composite }\end{array}$ \\
\hline $\begin{array}{c}\text { HPC } \\
\text { hot section) }\end{array}$ & Titanium aluminide & Titanium aluminide & $*$ \\
\hline HPT and LPT & $\begin{array}{c}5^{\text {th }} \text { generation } \\
\text { nickel-based alloy }\end{array}$ & $\begin{array}{c}5^{\text {th }} \text { generation } \\
\text { nickel-based alloy }\end{array}$ & $\begin{array}{c}\text { Nickel-based powder } \\
\text { metallurgy alloy }\end{array}$ \\
\hline Inlet/Nacelle & \multicolumn{2}{|c|}{ N/A } & $*$ N/A & Polymer matrix composite \\
\hline
\end{tabular}

TABLE 5.-PRINCIPAL MECHANICAL PARAMETERS FOR THE PODDED ENGINES

\begin{tabular}{|c|c|c|c|c|}
\hline & FPR1.4 & FPR1.5 & FPR1.6 & FPR1.7 \\
\hline Configuration & $\begin{array}{l}\text { Two- } \\
\text { spool } \\
\text { geared } \\
\text { turbofan }\end{array}$ & $\begin{array}{l}\text { Two- } \\
\text { spool } \\
\text { geared } \\
\text { turbofan }\end{array}$ & $\begin{array}{c}\text { Two- } \\
\text { spool } \\
\text { direct } \\
\text { drive } \\
\text { turbofan }\end{array}$ & $\begin{array}{c}\text { Two- } \\
\text { spool } \\
\text { direct } \\
\text { drive } \\
\text { turbofan }\end{array}$ \\
\hline Fan dia., inch & 126.6 & 115.1 & 106.8 & 100.3 \\
\hline $\begin{array}{l}\text { Fan } \\
\text { blade/Vane } \\
\text { counts }\end{array}$ & $18 / 46$ & $18 / 46$ & $18 / 46$ & $18 / 46$ \\
\hline $\begin{array}{l}\text { Max. fan tip } \\
\text { speed, ft/sec }\end{array}$ & 1119 & 1297 & 1450 & 1580 \\
\hline $\begin{array}{l}\text { Fan hub/tip } \\
\text { ratio }\end{array}$ & 0.31 & 0.31 & 0.31 & 0.31 \\
\hline $\begin{array}{l}\text { Fan stage } \\
\text { loading }\end{array}$ & 0.28 & 0.25 & 0.24 & 0.23 \\
\hline LPC stages & 2 & 2 & 5 & 4 \\
\hline HPC stages & 9 & 9 & 8 & 8 \\
\hline $\begin{array}{l}\text { HPC min. } \\
\text { blade ht. } \\
\text { (inch) }\end{array}$ & 0.62 & 0.69 & 0.73 & 0.79 \\
\hline HPT stages & 2 & 2 & 2 & 2 \\
\hline LPT stages & 3 & 3 & 6 & 5 \\
\hline $\begin{array}{l}\text { Fan nozzle } \\
\text { type }\end{array}$ & $\begin{array}{c}\text { Variable } \\
\text { area }\end{array}$ & $\begin{array}{c}\text { Variable } \\
\text { area }\end{array}$ & Fixed area & Fixed area \\
\hline $\begin{array}{l}\text { Total Engine } \\
\text { pod wt., lb }\end{array}$ & 19007 & 16191 & 15513 & 13314 \\
\hline $\begin{array}{l}\text { Bare engine } \\
\text { length, inches }\end{array}$ & 178.4 & 166.3 & 185.6 & 164.8 \\
\hline
\end{tabular}

5

This material is declared a work of the U.S. Government and is not subject to copyright protection in the United States. Approved for

public release; distribution is unlimited.
TABLE 6.-PRINCIPAL MECHANICAL PARAMETERS FOR THE EMBEDDED ENGINE

\begin{tabular}{|l|c|}
\hline \multicolumn{1}{|c|}{ Configuration } & Multiple fan system \\
\hline Fan dia., inch & 56 \\
\hline Fan blade/vane counts & $18 / 44$ \\
\hline Max. fan tip speed, ft/sec & 1297 \\
\hline Fan hub/tip ratio & 0.31 \\
\hline Fan stage loading & 0.25 \\
\hline LPC stages & 5 \\
\hline LPC blade/vane counts & $193 / 360$ \\
\hline HPC stages & 9 \\
\hline HPC blade/vane counts & $554 / 824$ \\
\hline HPC min. blade ht. (inch) & 0.68 \\
\hline HPT stages & 2 \\
\hline HPT blade/vane counts & $111 / 67$ \\
\hline LPT stages & 5 \\
\hline LPT blade/vane counts & $657 / 436$ \\
\hline Nozzle type & 2-D variable area \\
\hline $\begin{array}{l}\text { Engine weight (includes } \\
\text { accessories, with no } \\
\text { transmission), lb }\end{array}$ & 12,652 \\
\hline $\begin{array}{l}\text { Transmission \& lubrication } \\
\text { system weight, lb }\end{array}$ & 1,139 \\
\hline $\begin{array}{l}\text { Total engine weight (excludes } \\
\text { inlet), lb }\end{array}$ & 13791 \\
\hline
\end{tabular}

${ }^{*}$ Fan stage loading $=\frac{\Delta h}{\frac{1}{2} U_{t}^{2}(1+h / t)^{2}}$

$\Delta h=$ change in stagnation enthalpy

$U_{t}=$ blade tip speed

$h / t=$ blade hub-to-tip ratio 


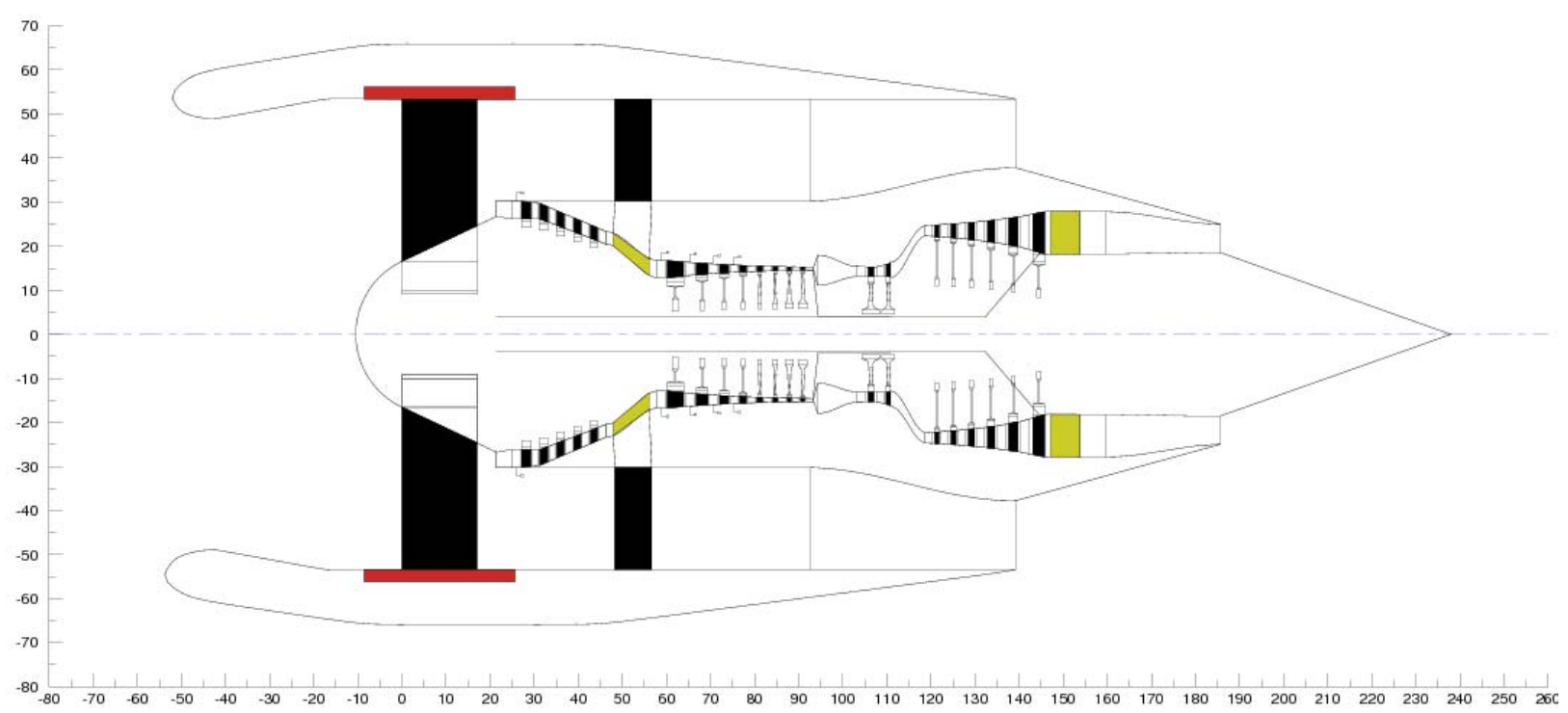

Figure 4. FPR1.6 podded engine internal layout (dimensions in inches).

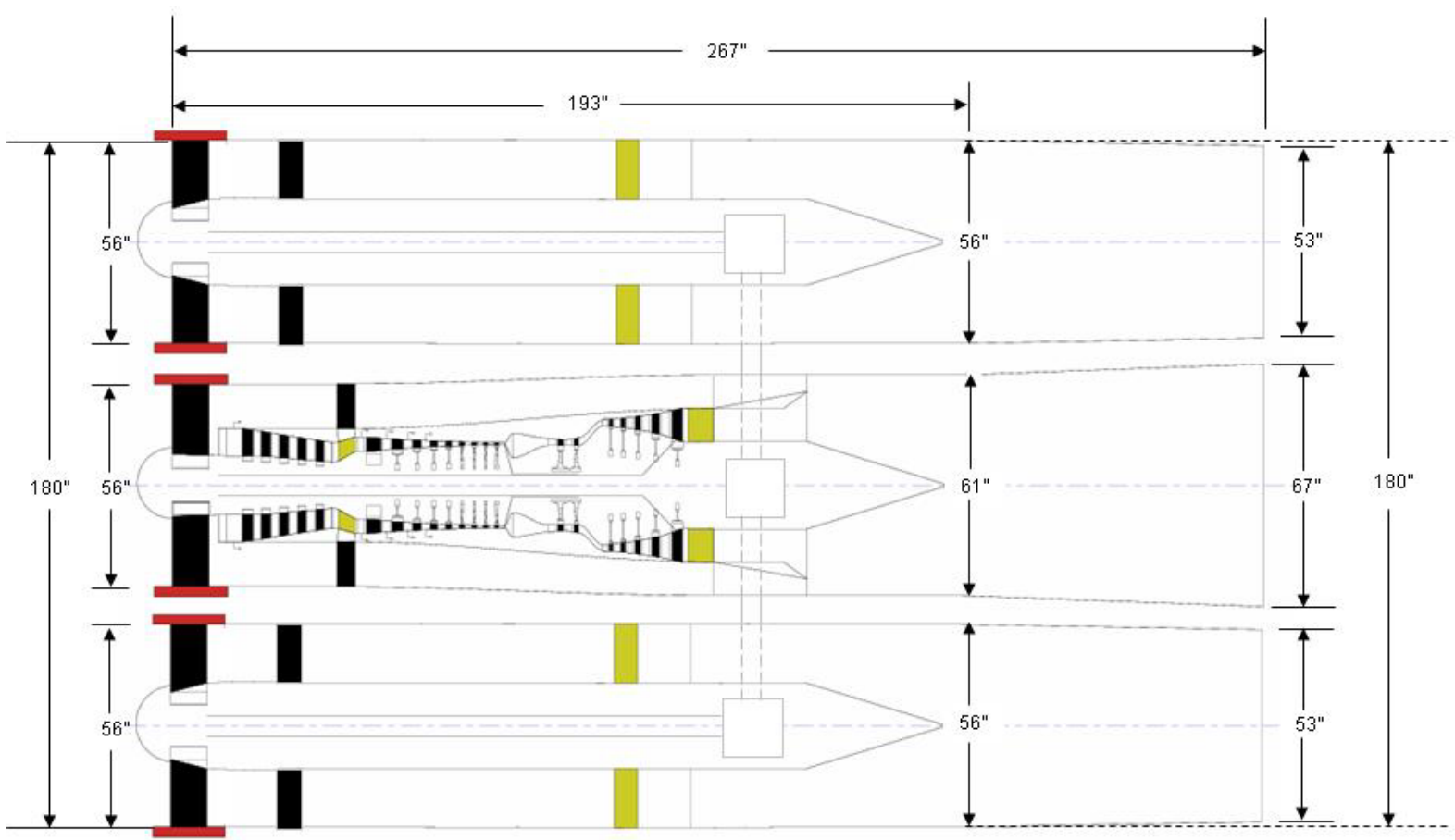

Figure 5. Embedded engine internal layout. public release; distribution is unlimited. 


\section{Transmission Design for the Embedded Engine}

Each embedded engine is composed of a gas generator that drove an inline fan and two additional fans through a mechanical drive train. The mechanical drive train was designed to be powered from the low pressure turbine (LPT) through angle gearboxes to adjacent fans. The gear-drive system configuration is shown in Figure 6.

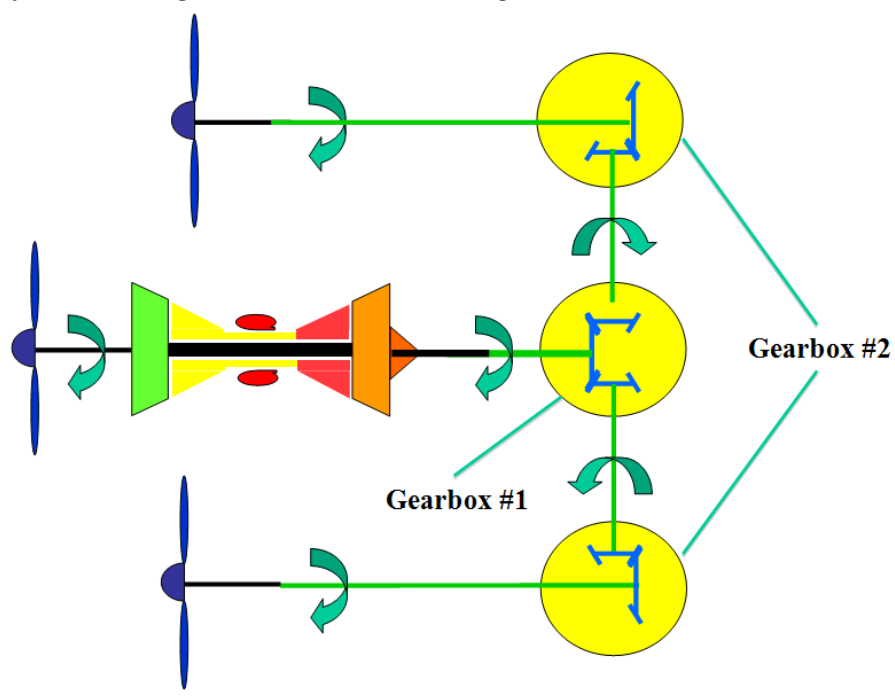

Figure 6. The gear-drive system configuration.

The gearboxes were designed using the calculation procedure for spiral bevel gears via the American Gear Manufacturers Association (AGMA, [15]). The load (power) was assumed to be split equally between the three fans. Therefore the gearbox driven directly by the power turbine was designed to transmit $\sim 35 \mathrm{khp}$ (Figure 6 , Gearbox \#1), or $2 / 3$ of the power, and then split the power to the adjacent gearboxes to drive the two parallel fans (Figure 6, Gearboxes \#2). The gearbox arrangements also considered overall size to minimize the cross-sectional area down stream of the turbine and fans. Gearbox \#1 was penalized during the design process since the pinion drives two gears. State-of-the-art materials and manufacturing processes would be required for all gearbox system components. The gearing design parameters are shown in Table 7.

\section{TABLE 7.-THE GEARING DESIGN PARAMETERS}

\begin{tabular}{|l|c|c|}
\hline \multicolumn{3}{|c|}{$\begin{array}{c}\text { Gearbox \#1 } \\
\text { Gearbox \#1 - 35528 hp, 5009 RPM } \\
\text { Gearbox \#2 - 17764 hp, 4994 RPM }\end{array}$} \\
\hline Number of teeth pinion / gear & $48 / 25$ & $27 / 52$ \\
Diametral Pitch (1/inch) & 2.5 & 3.0 \\
Spiral Angle (degrees) & 25 & 25 \\
Face Width (inches) & 3.5 & 3.25 \\
Outside Diameter (inch) & $19.41 / 10.94$ & $9.79 / 17.51$ \\
Pinion Bending Stress (KSI) & 64.3 & 67.2 \\
Gear Bending Stress (KSI) & 67.4 & 68.6 \\
Contact Stress (KSI) & 184.2 & 182.2 \\
Pitch Line Velocity (ft/min) & 25178 & 22660 \\
\hline
\end{tabular}

An empirical correlation, shown in Figure 7, was used to calculate the weight of the transmission and lubrication system. The correlation was developed based on actual weight data from over fifty rotorcrafts, tiltrotors, and turboprop aircrafts. They are also plotted in Figure 7. Using this parametric fit permitted gearbox weight to be estimated for the purposes of this study.

\section{Aircraft Mission and Sizing Studies}

With the engine data provided by GRC, Boeing used its BIVDS (Boeing Integrated Vehicle and Design System) tool suite to perform airplane mission and sizing analyses, based on an 11112-kilometers (6000 nautical miles) economic mission. The results have been reported in Reference 16. For the podded engines, they are summarized in Table 8.

\section{TABLE 8.-MISSION AND SIZING RESULT COMPARISONS} FOR THE PODDED ENGINES

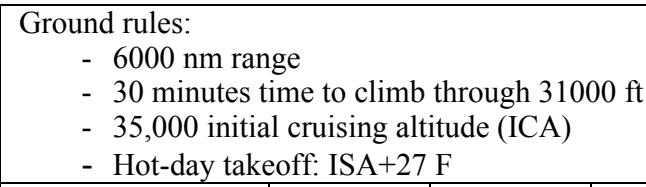

\begin{tabular}{|l|c|c|c|c|}
\hline $\begin{array}{l}\text { Fan pressure } \\
\text { ratio }\end{array}$ & 1.4 & 1.5 & 1.6 & 1.7 \\
\hline $\begin{array}{l}\text { Maximum } \\
\text { takeoff gross } \\
\text { weight, lb }\end{array}$ & 464,700 & 460,700 & 461,500 & 463,700 \\
\hline Payload, lbs & 103,000 & 103,000 & 103,000 & 103,000 \\
\hline $\begin{array}{l}\text { Static sea level } \\
\text { thrust, lbs }\end{array}$ & 74,862 & 71,837 & 69,757 & 68,258 \\
\hline Fuel burn, lbs & 118,573 & 120,939 & 125,051 & 129,127 \\
\hline $\begin{array}{l}\text { Engine Out } \\
\text { field length, ft }\end{array}$ & 6,214 & 5,942 & 6,196 & 6,320 \\
\hline
\end{tabular}

Boeing used the fuel-burn trend band for current cargo freighters (B767-300ER, A330-200, etc.) for the comparison. It showed that the N2A (with FPR1.6 podded engines) exceeds $\mathrm{N}+2$ fuel burned goal at $-29 \%$. Although both the FPR1.4 and FPR1.5 geared engines had lower fuel burn, the FPR1.6 engine was deemed to have lower risk for the 2020 IOC time frame. It was selected for the noise study. With the embedded engines, the N2B met the fuel-burn goal at $-25 \%$. Those results are summarized in Table 9.

\section{TABLE 9.-MISSION AND SIZING RESULTS} FOR THE EMBEDDED ENGINE

\begin{tabular}{|c|c|c|}
\hline $\begin{array}{c}\text { Ground } \\
- \\
- \\
- \\
-\end{array}$ & \multicolumn{2}{|c|}{$\begin{array}{l}6000 \mathrm{~nm} \text { range } \\
30 \text { minutes time to climb through } 31000 \mathrm{ft}\end{array}$} \\
\hline Fan pre & ssure ratio & 1.5 \\
\hline Maxim & Im takeoff gross weight, lb & 477,400 \\
\hline Payloa &, $\mathrm{lb}$ & 103,000 \\
\hline Static s & ea level thrust, $1 \mathrm{~b}$ & 48,320 \\
\hline Fuel bu & $\mathrm{nn}, \mathrm{lb}$ & 130,300 \\
\hline Engine & out field length, $\mathrm{ft}$ & 5436 \\
\hline
\end{tabular}

This material is declared a work of the U.S. Government and is not subject to copyright protection in the United States. Approved for public release; distribution is unlimited. 


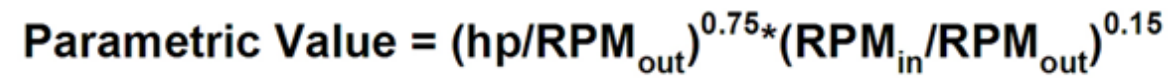

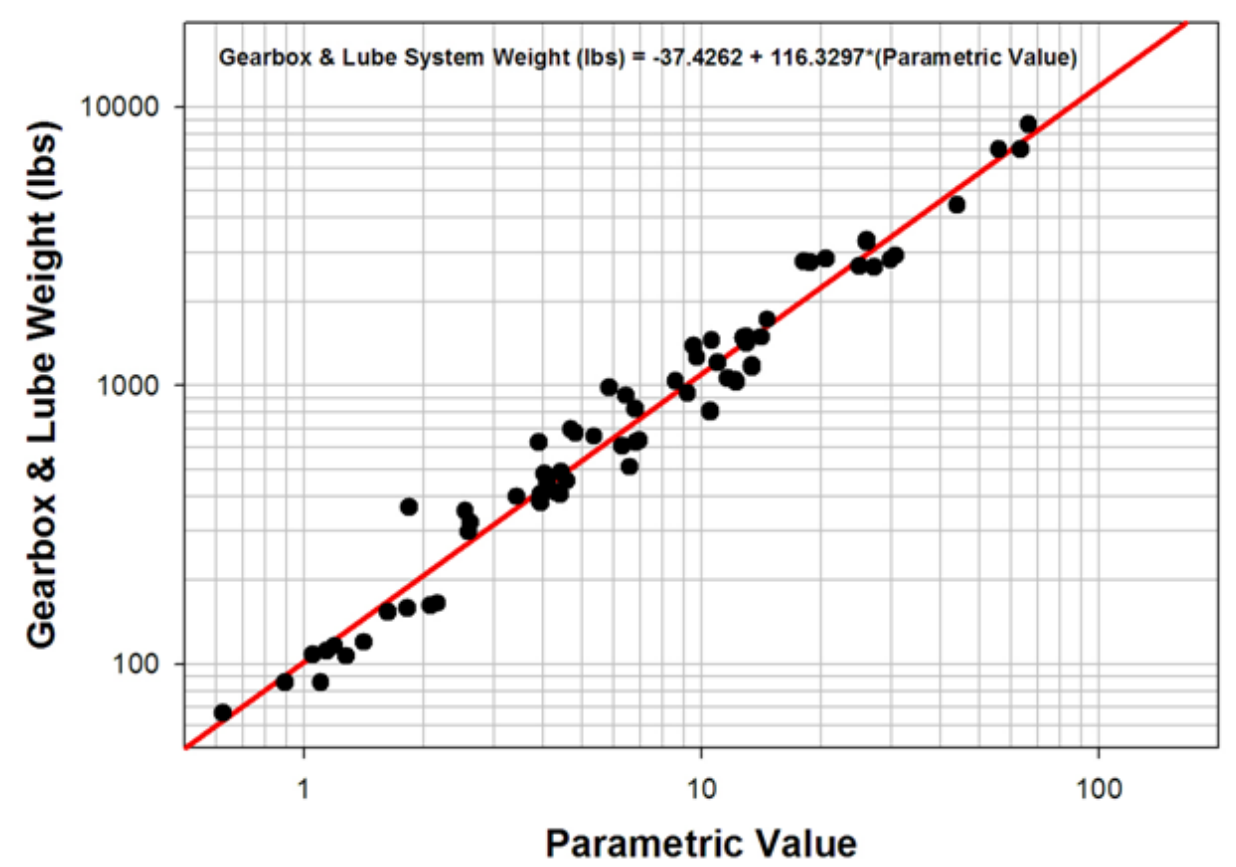

Figure 7. Rotorcraft transmission and lubrication system weight data.

\section{Aircraft and Engine Noise Studies}

Subsequent noise studies were also conducted by Boeing and MIT. The methodology and results are reported in Reference 16. The noise estimate for the N2A was shown to be $-47 \mathrm{~dB}$ below Stage 3 (or $-37 \mathrm{~dB}$ below Stage 4), within $5 \mathrm{~dB}$ of the $\mathrm{N}+2$ goal. For the N2B, the noise was shown to be $-26 \mathrm{~dB}$ below Stage 3 (or $-16 \mathrm{~dB}$ below Stage 4 ). Based on the results, Boeing concluded that the $\mathrm{N}+2$ noise goal is achievable with $\mathrm{N} 2 \mathrm{~A}$ configuration, with increased jet shielding, increased climb speed, additional focus on landing gear fairings, and with continuing R\&D on HWB type aircraft. For the N2B, increasing the duct treatment (e.g. with acoustic tiles) and reducing the jet velocity will help it move towards the $\mathrm{N}+2$ noise goal. A part of the continuing $R \& D$ is the need to further improve noise prediction methodologies, especially for an embedded engine.

\section{SUMMARY}

NASA GRC conducted engine conceptual design studies on two engine concepts, podded and embedded systems, that were proposed for a HWB freighter aircraft for the ' $N+2$ ' timeframe. The results were provided to Boeing Phantom Works to support its investigation to develop a HWB subsonic freighter configuration with noise prediction methods to meet the NASA Subsonic Fixed Wing N+2 noise and fuel burn reduction goals. Based on its Phase 1 results, Boeing has concluded that the $\mathrm{N}+2$ fuel burn and noise goals are achievable on a hybrid wing type vehicle, with continuing R\&D on HWB type aircraft and improvement of noise prediction methodologies.

\section{ACKNOWLEDGMENT}

The authors would like to acknowledge Dr. Timothy Krantz of the Army Research Laboratory for the development of the gearbox and lubrication system weight correlation used in this study, and Mr. Christopher Snyder for his comments on the paper.

\section{REFERENCES}

[1] The Boeing Company, "Current Market Outlook 20082027," July 9, 2008. Retrieved on November 10, 2008 from: http://www.boeing.com/commercial/cmo/pdf/Boeing_Current Market_Outlook_2008_to_2027.pdf

[2] Airbus, "Global Market Forecast 2007-2026," 2007. Retrieved on November 10, 2008 from: http://www.airbus.com/fileadmin/documents/gmf/ PDF_dl/00-all-gmf_2007.pdf

[3] National Research Council, "Securing the Future of U.S. Air Transportation: A System in Peril," Washington, DC, National Academy Press, 2003

[4] National Research Council, "For Greener Skies," National Academy Press, 2002.

[5] Cambridge-MIT Institute, "Silent Aircraft Conceptual Design," November 6, 2006.

[6] Hall, C.A. and Crichton D., "Engine Design Studies for a Silent Aircraft," Journal of Turbomachinery, 129, July, 2007.

[7] Liebeck, R.H., "Design of the Blended Wing Body Subsonic Transport," Journal of Aircraft, 41, No. 1, January February, 2004.

This material is declared a work of the U.S. Government and is not subject to copyright protection in the United States. Approved for public release; distribution is unlimited. 
[8] NASA-Industry Cooperative Effort, "Numerical Propulsion System Simulation User Guide and Reference," Software Release NPSS 1.5.0, May 7, 2002.

[9] Lytle, J.K., "The Numerical Propulsion Simulation: An Overview," NASA TM-2000-209915.

[10] Kirby, M.R., "Environmental Design Space, Tool Developments Enhancements," Semi-annual progress report, US Department of Transportation/Federal Aviation Administration, Project No. 1606A75, Contract No. 07-C-NEGIT-1, May 2008.

[11] Onat, E. and Klees, G.W., "A Method to Estimate Weight and Dimensions of Large and Small Gas Turbine Engines," NASA CR-159481, 1979.

[12] Tong, M.T., Halliwell, I., Ghosn, L.J., "A Computer Code for Gas Turbine Engine Weight and Life Estimation," ASME Journal of Engineering for Gas Turbine and Power, volume 126, no. 2, April 2004.
[13] Tong, M.T., Naylor, B.A., “An Object-Oriented Computer Code for Aircraft Engine Weight Estimation," GT2008-50062, ASME Turbo-Expo 2008, June 9-13, 2008.

[14] Geiselhart, K., Berton, J.J., Tong, M.T., "Shape Memory Alloy Variable Area Fan Nozzle," NASA REVCON ISAT Report, April 2001.

[15] American Gear Manufacturers Association Standard, 2003A86,"Rating the Pitting Resistance and Bending Strength of Generated Straight Bevel, Zerol Bevel, and Spiral Bevel Gear Teeth", January 1992.

[16] Kawai, R. and Brown, D., "Acoustic Prediction Methodology and Test Validation for an Efficient Low-Noise Hybrid Wing Body Subsonic Transport," Phase I Final Report PWDM08006A, NASA Contract Number NNL07AA54C, October, 2008.

This material is declared a work of the U.S. Government and is not subject to copyright protection in the United States. Approved for public release; distribution is unlimited. 